GLOBAL JOURNAL OF EDUCATIONAL RESEARCH VOL 19, 2020 39-53

COPYRIGHT® BACHUDO SCIENCE CO. LTD PRINTED IN NIGERIA. ISSN 1596-6224

53 www.globaljournalseries.com; Info@globaljournalseries.com

\title{
INFLUENCE OF HEADTEACHERS' MONITORING ALLOCATIONS OF TEACHING AND LEARNING MATERIALS ON LEARNERS' PERFORMANCE IN ACTIVITY AREAS IN PUBLIC PRE-PRIMARY SCHOOLS IN NAROK COUNTY, KENYA
}

KOSILEI JOHN KIPKOECH, DR. ANDREW KIBET KIPGOSGEI AND DR. VIVILINE NGENO

(Received 27, April 2020; Revision Accepted 6, May 2020)

\begin{abstract}
The role of headteachers in the management of teaching and learning materials although widely studied has not been explored in regard to its influence on learners' performance in public pre-primary Schools. The purpose of this study is to determine the influence of monitoring allocation of teaching and learning materials by Headteachers on learners performance in activity areas. Convergent Mixed Method design was used as it enabled the researcher to handle both qualitative and quantitative data that was collected. The target population comprised of 735 pre-primary schools, 735 Headteachers, 1470 preschool teachers, 30 ECD Coordinators, and 6 Quality Assurance Standards Officers. The sample size included 85 pre-primary schools, 85 head teachers, 85 pre-primary teachers from public pre-primary schools, 6 Quality Assurance and Standards Officers and 9 ECD Coordinators. Purposive sampling was used in the selection of headteachers, while the sample for teachers, ECD Coordinators, and Quality Assurance Standards Officers was selected using simple random sampling technique. The researcher used questionnaires, Interview schedule, Center Performance Assessment Tool, and Center Observation Checklist as the main tools for collecting data. The researcher used qualitative and quantitative approaches in analyzing data. Regression Analysis was used to test the hypotheses. The results show that monitoring allocation of teaching and learning materials by Headteachers did not have a statistically significant influence on learners' performance in activity areas.
\end{abstract}

KEYWORDS: Monitoring Allocations of Teaching and Learning Materials, Learners' Performance, Activity Areas, Pre-schools

\section{INTRODUCTION}

Early Childhood Education (ECE) is an education given to children in pre-primary schools before beginning primary school (Oluwafemi, Nma, Osita \& Olugbenga 2014). The United Nations
Educational and Cultural Organization (UNESCO) (2010) describes early childhood as a period from birth to 8 years. This is the time when the brain develops significantly (Landrum \& McDuffie, 2010). Pre-primary offers a strong teaching foundation and contributes to the

Kosilei John Kipkoech, Department of Curriculum, Instructional and Educational Media, University of Kabianga

Andrew Kibet Kipgosgei, Department of Curriculum, Instructional and Educational Media, University of Kabianga

Viviline Ngeno, Department of Education, Administration, Planning, Management, Psychology \& Foundations, University of Kabianga. 
development of abilities, understanding, private information and trust, and a sense of social responsibility (Hirst, Jewis, Sojo \& Cavanagh, 2011).

The United Nations Convention (1989) states that every child has the fundamental right to learn and develop his /her full potential through access to quality education regardless of age, gender, background or social background. High-quality education is partly effective management of education and learning materials. In public kindergartens, the management of teaching and learning materials is the responsibility of the Headteachers.

Montessori (1998) pointed out that the use of concrete teaching and learning materials helps to develop five senses for children. This reduces the teacher's monotony of using only one material to improve learning. Karaka (2009) pointed out that concrete materials improve the understanding of basic concepts. Facilitation of learning in classroom by the teacher is subject to the effective management of teaching and learning resources. Everything the teacher prepares does not necessarily make sense if the child cannot learn. If the materials are displayed properly, they occupy the mind of the learners when the teacher is not in class. This will improve children's learning in the absence of the teacher.

The main goal of the teaching and learning process is to bring about a significant change in behavior through active involvement and critical thinking of the learner. This cannot happen without the availability of educational and learning resources (Afework \& Asfaw, 2014). It is therefore important that the administration of primary schools ensure the availability and adequacy of these resources. The question of availability and use of teaching and learning materials for pre-primary schools arises because the materials are important in the teaching of any subject. Preschool teachers can testify that teaching becomes easier with such materials (Mwonga \& Wanyama, 2012).

A study by Offenheiser and Holcombe (2008) has shown that inadequate teaching and learning resources, lack of well-ventilated classrooms, adequate furniture, safe and clean water, playgrounds, toilets, and toys have a negative influence on the implementation of Early Child Development Education (ECDE) programs. This means that teaching and learning materials need to be adequately managed. The management of teaching and learning resources involves allocation, organizing, directing, monitoring and evaluating the use of these resources to achieve the school's stated goals. Teachers in preprimary develop and source for teaching-learning resources.

It is the responsibility of school headteachers to ensure that materials are availed to the teachers on time and in the right quantity (Tuimur \& Chemwei, 2015). Moreover, there should be regular monitoring of the instructional materials to avoid loses (Ministry of Education, 2017). Monitoring the allocation of teaching and learning materials to pre-primary teachers is critical for preschool effectiveness. There is a need for proper allocation of teaching and learning materials to pre-primary teachers to enable them to deliver effectively to the learners (MascittiMiller, 2012).

Kenya has signed the United Nations Convention as a country and passed several laws to ensure that all children are entitled to their constitutional rights, as laid down in the 2010 Kenyan constitution. In this perspective, primary school management ought to provide adequate varied teaching and learning resources in pre-primary schools. Children draw their own conclusion in the teaching and learning process by use of educational resources, as such, they must be given the space to solve their own problems individually or in groups by material processing, this increases their self-esteem. Many ECDE Centers in Kenya do not have sufficient teaching and learning resources and facilities suitable for ECDE in their learning environment.

Mwonga and Wanyama (2012) found that children, when exposed to different teaching and learning resources, are usually active and involved in the learning process. Therefore, headteachers need to monitor allocation of teaching and learning materials. This because without adequate and relevant materials, meaningful teaching and learning cannot take place. This also applies to the implementation of the curriculum (Ntumi, 2016). The teaching and learning materials include study books, teaching material, and stationery, to enable the officially planned curriculum to be implemented as planned so that teachers and learners can properly fulfill their role in the curriculum implementation process.

The Government of Kenya has also achieved remarkable results in providing teaching and learning materials (Republic of Kenya, 2012). However, these materials have not been sufficient as the government provided only essential materials and the government for financial reasons has not paid attention to the development and training of infants in this system 
(ECDE). This brings into focus the management roles of headteachers in the acquisition and utilization of teaching and learning materials in public pre-primary schools. The focus of the study is on the school headteachers' management roles because the headteachers are the school managers and that any other manager in the school would be performing a delegated function of the headteacher.

The study specifically, focuses on public preprimary schools in Narok County. This is informed by the fact that the Narok County Education Office (2018), Department of Quality Assurance and Standards office reported that poor performance among preschoolers in public ECD centers was one of the pressing concerns that require urgent attention.

\section{STATEMENT OF THE PROBLEM}

Educational research in the background suggests that a good foundation in the educational phase of a child is essentially a good primary education and a higher secondary education. Effective management of teaching and learning materials as reviewed, influences learning outcomes in a school. Teaching and learning materials need to be of good quality, quantity, adequate, available and should also be relevant. Headteachers' management roles is critical in the allocation, maintenance and utilization of teaching and learning materials in public pre-primary schools. Research that relates to the headteachers' monitoring of teaching and learning materials with learning outcomes in pre-primary education in Kenya is scanty. Most studies focus on public elementary and middle schools (Orodho Waweru, Ndichu \& Nthinguri, 2013).

Moreover, study on the influence of managerial roles of Headteachers such as monitoring allocations of teaching and learning materials on learners' performance in activity areas is limited in most parts of the country, Narok County included. Furthermore, although some studies suggest that the management of teaching and learning materials by Headteachers may have a negative or positive impact on learner performance, the influence of teaching and learning materials management on learner performance in pre-primary schools has not been explored. Therefore, this study is critical, in that it intends to unearth the underlying factors that cause poor performance in Activity Areas in public pre-primary schools in Narok County.

\section{OBJECTIVE}

The objective of the study was to examine the influence of headteachers' monitoring allocations of teaching and learning materials on learners' performance in activity areas in public preprimary schools in Narok County, Kenya

\section{Hypotheses:}

$\mathrm{Ho}_{1}$ : There is no significant influence of monitoring of allocation of teaching and learning materials by headteachers on learners 'performance in activity areas, in public preprimary schools in Narok County.

\section{LITERATURE REVIEW \\ Early Childhood Education}

Eddy (2016) describes Early Childhood Education (ECE); also known as pre-school education, as an area of educational theory that relates to the education of young children (formal and informal) from birth up to the age of about eight years. The education of children and babies, a subset of pre-school education, refers to the education of children from birth to the age of 8 years. It developed into a research area during the Enlightenment, especially in European countries with a high literacy rate.

Hirst, Jewis, Sojo, and Cavagh (2011) argue that education for young children is of great value to all children and should be available to everyone. They argue that kindergarten provides a solid foundation for learning and helps to develop skills, knowledge, personal competence and selfconfidence, as well as social responsibility. That is why every child must have access to good preschool education. The researchers noted that there is a wide range of positive developments and experiences in different countries, including increasing teacher participation and career development to increase the number of enrollments and transitions. It was noted in their comment that the transition to the next level of learning depends on the teaching and learning materials management in kindergartens. The purpose of this study is to investigate the Influence of Teaching and Learning resources management on learners' performance in activity areas in public pre-primary schools.

Muithungu (2003) suggests that teachers should use different teaching and learning resources that are easy to find in the environment. It is the responsibility of stakeholders which include the headteacher to ensure that the necessary materials are made available to improve children's learning in ECDE centers. The researcher noted that the teacher is the primary 
source of teaching materials because he/she initiates their provision in the centers, for example by involving the children in the materials collection; however, it is the responsibility of the teacher to provide materials. ECD teachers liaise with the headteacher in the selection and ordering of Teaching and Learning materials.

In this study, the researcher focuses on the Heads management and oversight role in the acquisition and use of teaching and learning materials in pre-school education.

\section{MONITORING ALLOCATIONS OF TEACHING AND LEARNING MATERIALS}

Mascitti-Miller (2012) noted that the provision of resources at the local level offers those closest to learners the chance to make the best decisions to meet the needs of their school community thereby improving learner performance. Gupta (2001) noted that the question of internal efficiency is ultimately linked to the issue of resource allocation and use. It is important to understand the distribution of resources in schools for two reasons. First, schools create education, and the level and quality of the resources they receive are crucial in determining the performance of learners. Resource allocation and utilization is a management function in schools, therefore, this study will investigate the influence of teaching and learning materials on learners' performance.

Usman (2016), from a Nigerian context, stated that it is the responsibility of the administration of a school institution to bring together and effectively allocate different resources to achieve the overall goals of the institution (National Teachers Institute, 2006). However, the researcher noted that this was not good in most Nigerian schools, resulting in open conflict over available resources.

Okendu (2012) in Kenya observed that within the school system of effective teaching and learning, not enough emphasis was placed on collecting human and material resources collectively from education administration. On this basis, it was suggested that the headteacher take on the role of administrators and caretakers in public kindergartens, including trainers and if necessary, participate in educational activities. To live up to their responsibility for improving and developing teaching in the school system, all staff, trained and untrained must be available. This is possible by using the available resources allocated to schools to achieve educational goals. Okendu's suggestions showed the crucial roles of headteachers in resource allocation.
In a study by Mbaka (2012), in the district of Gucha Sub-county in Kenya, it was concluded that school Heads need a focus and vision for school management to avoid imbalances in resource allocation and use. The study found that good results are related to the resources allocated to them during exams. If this parameter was not recognized, it became very difficult to understand why a school continued to perform poorly during national tests. The study by Mbaka agrees with this study as it will examine the role of Headteachers in the allocation and use of resources in relation to performance.

Wambua (2015) found in a study in the County of Makueni in Kenya that the most important factors that determine the assignment of teaching material and learning materials are the class size of learners or their enrollment by subject and in schools. Wambua argued that if the teaching materials were not properly assigned, it demotivated both the teacher and the learner and resulted in poor performance in related topics and activities. The study by Wambua is related to this study in that it highlights the relationship between resources and performance.

\section{THEORETICAL FRAMEWORK}

The theoretical framework is the justification of the investigation. It provides the reason for searching for new data as well as for the analysis, interpretation, and synthesis of this data. The framework also lists the theories on which the study is anchored to determine the relationship between the variables in the study (Labaree, 2009). The study was supported by the Education Production Theory by Hanushek (1995).

\section{EDUCATION PRODUCTION THEORY}

The study employs Education Production Theory (EPT), which was developed by Hanushek (2008). This theory outlines the process by which inputs are converted into outputs. Hanushek (1995) affirms that the production function approach is the most appealing and useful in explaining the determination of pupils' achievements. There is little consensus in the definition of and measurements of inputs and outputs of education. However, the issue seems to arise from lack of agreed goal of education that can be translated to operational and measurable objectives, hence there is no standardized unit of outputs and inputs. Thus, inputs are all Teaching Learning Resources [TLR], to include Teaching Learning Materials [TLM], qualified teachers and the school physical facilities. In other words, the 
quality of teaching and learning materials has an influence on learner performance. The applicability of the theory in the study can be seen in the fact that all the theoretical concepts with headteachers' monitoring of the allocation of teaching and learning materials are conceptualized to have a bearing on learners' performance.

\section{RESEARCH METHODOLOGY}

This research design used was convergence mixed methods design. This research design was chosen because the researcher collects and analyzes both qualitative and quantitative information over a comparable period of the research process, and then the two outcome agreements presented in a general interpretation. The research was conducted in Narok County. The County is located in the South Rift region of Kenya, formerly known as the Rift Valley province. Narok County is bordered by Nakuru County in the north, Kajiado in the east, Bomet in the west, and Tanzania in the south. Narok County has six educational sub-counties: Narok North, Narok East, Narok South, Narok West, Transmara West, and Transmara East. The researcher selects Narok County in that the performance trends in activity areas, as well as transition to standard one, have remained unimpressive over the past decade (Narok County Education Office, 2018).

The target population was 735 pre-schools, from which an accessible population of 1470 preschool teachers and 735 head teachers of public primary schools in Narok County were reached (See Table 1). The target population also included six quality assurance and standards officers of the sub-counties and 30 ECD coordinators.

Table 1: Target Population

\begin{tabular}{llll}
\hline Sub County & No. of Schools & Head Teachers & Teachers of Preschool \\
\hline Narok North & 176 & 176 & 352 \\
Narok East & 83 & 83 & 166 \\
Narok South & 148 & 148 & 296 \\
Narok West & 123 & 123 & 246 \\
Transmara West & 126 & 126 & 252 \\
Transmara East & 79 & 79 & 158 \\
Total & $\mathbf{7 3 5}$ & $\mathbf{7 3 5}$ & $\mathbf{1 4 7 0}$ \\
\hline
\end{tabular}

Source: Narok County Education Office (2018).

All pre-schools in Narok County provide the sample framework for the study. The selection framework consisted of pre-primary schools, Headteachers and pre-primary teachers who are responsible for their respective pre-schools.

A stratified random selection was used in this study, whereby the strata comprised ofHead Teachers, Quality Assurance Officers and ECD
Coordinators. The sample size of the pre-primary schools in the study has been calculated according to a scientific formula from Kothari (2004).

Purposive sampling was used to sample 85 head teachers and 85 pre-school teachers (those in charge of every pre-school) 
Table 2: Sample Distribution Matrix

\begin{tabular}{lllll}
\hline Sub County & $\begin{array}{l}\text { No. of } \\
\text { Schools }\end{array}$ & $\begin{array}{l}\text { Population } \\
\text { Proportion } \\
\text { (PP) }\end{array}$ & $\begin{array}{l}\text { Head Teachers } \\
\text { (PP x 85) }\end{array}$ & $\begin{array}{l}\text { Teachers I/C of } \\
\text { Preschool (PP x 85) }\end{array}$ \\
\hline Narok North & 176 & $24 \%$ & 20 & 20 \\
Narok East & 83 & $11 \%$ & 10 & 10 \\
Narok South & 148 & $20 \%$ & 17 & 17 \\
Narok West & 123 & $17 \%$ & 14 & 14 \\
Transmara West & 126 & $17 \%$ & 15 & 15 \\
Transmara East & 79 & $11 \%$ & 9 & 9 \\
Total & $\mathbf{7 3 5}$ & $\mathbf{1 0 0 \%}$ & $\mathbf{8 5}$ & $\mathbf{8 5}$ \\
\hline
\end{tabular}

Source: Author, (2018)

Table 1 above shows that one Headteacher and one pre-school teacher are selected from each of the 85 primary schools. The percentage column was computed by taking the school population for each sub-county and dividing the same with the total target population for schools (735) and then multiplying the result by 100 to get the percentage to ensure proportionality among the six sub-counties of Narok County. The sample was divided proportionally to the six sub-counties of Narok County based on the population share. The choice of these respondents uses a purposive sampling method.

Census sampling technique was used when sampling Quality Assurance Officers from the six Sub-counties to be polled, each representing a Sub-county. Census technique is suitable in this case because it is economical and given the small size of this population (Farooq, 2013). This method had a high degree of accuracy and allows the researcher to represent the six geographical regions of the County.

The study used $30 \%$ of the population as the sample for ECD Coordinators, as informed by a recommendation by Gall, Gall and Borg (2003). Given that the population for these coordinators is 30 , it means $30 \%$ of $(30)$ which is 9 ECD coordinator, when it is divided into the Six subcounties, it translates to 1.5 , (that is 2 ECD Coordinators per Sub County). Therefore, 10 ECD Coordinators were selected for the study, using a simple random sampling technique.

Primary data was collected via self-directed (oneto-one) semi-structured questionnaires and interview plans. Questionnaires were used to gather data from school Headteachers and preschool teachers while the survey schedule is used to gather data from quality assurance officers and ECD coordinators. An observation checklist was also kept at 85 pre-school schools to determine the availability and adequacy of teaching and learning materials.

The interview schedules contained closed and open questions that were suitable for collecting qualitative data. They were used to collect data from the Quality Assurance Officers of Sub Counties and the ECD coordinators for all five research objectives.

The survey also collected secondary data from preschool teachers by reviewing learner progress records to verify performance. In the current Competency-Based Curriculum (CBC), Assessment Rubrics are used to check learning outcomes. A rubric is a teacher-generated tool that maps the specific learning outcomes that specify performance, level of success and mastery of the outcomes. Rubrics are meant to measure the product, process, and progress of learning $(K I C D, 2017)$. The Curriculum designs used parameters such as exceeding expectations, meeting expectations, approaching expectation and below expectations as levels of performance in pre-primary school.

In Bomet County, a pilot study was carried out at nine public pre-schools $(10 \%$ of the sample size of the 85 pre-schools). It ensured that selected pilot schools were not included in the sampled schools. The pilot study detected shortcomings in the questionnaires before the final data collection was carried out (Cooper \& Schindler, (2013). Using test experiments, the researcher can determine whether respondents understand the instructions and questions in the research tools or not. Pilots, therefore, determined the reliability and validity of the research instrument. 


\section{VALIDITY AND RELIABILITY OF THE INSTRUMENT}

The study conducted both Content validity and Construct validity. These types of validity of instruments were determined by consultation with university experts, from the University's Department of Education Planning and Management and the regulatory authorities, as this type of validity is not statistically measurable. The internal consistency of the instruments was tested by calculating Cronbach alpha reliability coefficients from the pilot studies using the benchmark with coefficient values greater than 0.7 . Reliability of the instruments was tested by computing Cronbach Alpha coefficients reliability using Test Retest approach from the pilot study data. Orodho (2008) states that a correlation coefficient of $>0.7$ is considered reliable to collect quality data for a study. Instruments scored a correlation coefficient of $>0.7$, and thus, were considered reliable and adapted for the study.

\section{DATA COLLECTION PROCEDURES}

The researcher requested for an introductory letter from the University of Kabianga to introduce the investigator to the respondents and Educational authorities. The permit and introductory letter were presented to the school Headteachers, who gave the researcher permission to carry out the research at preprimary schools.

The researcher applied for a research permit at National Commission for Science Technology and Innovation (NACOSTI). The permit was used to receive an introductory letter from the Director of Education in Narok County. The data collection tools were administered to respondents in person by the researcher.

\section{DATA ANALYSIS AND PRESENTATION}

The data in the questionnaires were processed to remove inconsistencies. The processing ensures that the answers are complete, accurate and suitable for further processing. The data was then encoded and finally analyzed electronically with Social Science Statistics Version 23 (SPSS).

Quantitative data was analyzed using both descriptive and inferential statistics. First, the descriptive statistics such as frequencies, averages, and percentages. Regression analyses were computed to determine the relationships between the variables in the study, as stated in the null hypotheses $\mathrm{H}_{01}-\mathrm{H}_{04}$. The regression analysis involved the computation of the ANOVA, t-tests, Beta value $(\beta)$, as well as the $p$ values. The golden rule is to reject the null hypothesis when the $p$-value is less than 0.05 significant test $(p<0.05)$ and accept the null hypothesis when the $p$-value is greater than 0.05 ( $p>0.05)$.

The following regression model will guide the study.

$$
\begin{aligned}
& \hat{y}=b x+a \text { (or, } \\
& \hat{y}=\beta_{1} x+\beta_{0} \text { ) }
\end{aligned}
$$$$
\text { equivalently, }
$$

where:

$$
\begin{aligned}
& x=\text { a value on the } x \text { axis } \\
& b=\text { slope parameter } \\
& a=\text { intercept parameter (i.e., value on } y
\end{aligned}
$$

axis where $\mathrm{x}=0$ [not shown above])

$$
\hat{y}=\text { a predicted value of } y
$$

LPAA $=\beta_{0}+\beta_{1}$ MATLM $+\varepsilon$

Where:

LPAA=Learners' Performance in Activity Areas

MATLM= Monitoring Allocations of Teaching and Learning Materials

$\beta_{0}=$ regression Constant

$\beta_{1}$ : Regression coefficients for independent variables

$\varepsilon=$ Error/Disturbance Term assumed to be normally distributed

The categorical variables for the regression are as follows:

$\mathbf{H}_{02}$ : Headteachers' monitoring allocations of teaching and learning materials and learners' performance in activity areas

The results for quantitative data were presented in the form of tables (tabular summaries) and charts (pie charts, graphs, and bar charts).

Qualitative data, which was collected from interview schedules and the ECD Centre teaching-learning materials observation checklist will be analyzed using Thematic Textual Analysis. This approach involved sorting and classification of related themes emerging from the responses. The classification was according to the study objectives. The results were presented in prose form (Narrations).

\section{ETHICAL CONSIDERATION}

The research ensured that the permit to conduct the investigation was collected from the relevant authorities prior to the data collection. To ensure ethical behavior during the research process, the researcher sought and obtained written permission to conduct this research from the National Commission for Science, Technology, 
and Innovation (NACOSTI). The researcher then used the obtained permission to obtain approval from the Narok County Education Bureau to ensure that it is a legal exercise. Researcher also ensured that participants are treated with the highest respect and are aware that their participation is voluntary. Participants were fully informed about the purpose of the investigation and receive confidentiality and anonymity, as their identity and the information they provide remains confidential and anonymous. The participants were not exposed to any emotional stress because their participation is voluntary.

\section{RESULTS AND DISCUSSIONS}

\section{Respondents Response Rate}

The study was able to obtain a response from 81 headteachers and 85 teachers, thus translating to an average rate of $97.65 \%$. This was adequate to enable the researcher to come up with reliable conclusions and recommendations. Dommeyer,
Baum, Chapman, and Hanna, (2002) reported that the acceptable response rate for on-paper surveys is $75 \%$, therefore the attained percentage was good and found acceptable to the researcher.

\section{DEMOGRAPHIC CHARACTERISTICS \\ Gender/Sex of the Respondents}

The results in Table 3 and Figure 1 show that $66.7 \%$ of the headteachers and $21.2 \%$ of the teachers were male respondents, while $33.3 \%$ of the headteachers and $78.8 \%$ of the teachers were female respondents. This implied in majority of the preschools, male respondents occupied headteachers positions, while majority of the preschool teachers were female. Likwop (2016) found that there were more male headteachers than female headteachers in Narok County. This result reveals a similar pattern, thus showing there are few women in school leadership in the county.

Table 3: Gender /Sex of Respondents

\begin{tabular}{llllll}
\hline & & \multicolumn{2}{c}{ Headteachers } & \multicolumn{2}{c}{ Teachers } \\
& & F & \% & F & \% \\
\hline Gender /sex of respondent & Male & 54 & $66.7 \%$ & 18 & $21.2 \%$ \\
& Female & 27 & $33.3 \%$ & 67 & $78.8 \%$ \\
& Total & $\mathbf{8 1}$ & $\mathbf{1 0 0 . 0 \%}$ & $\mathbf{8 5}$ & $\mathbf{1 0 0 . 0 \%}$ \\
\hline
\end{tabular}

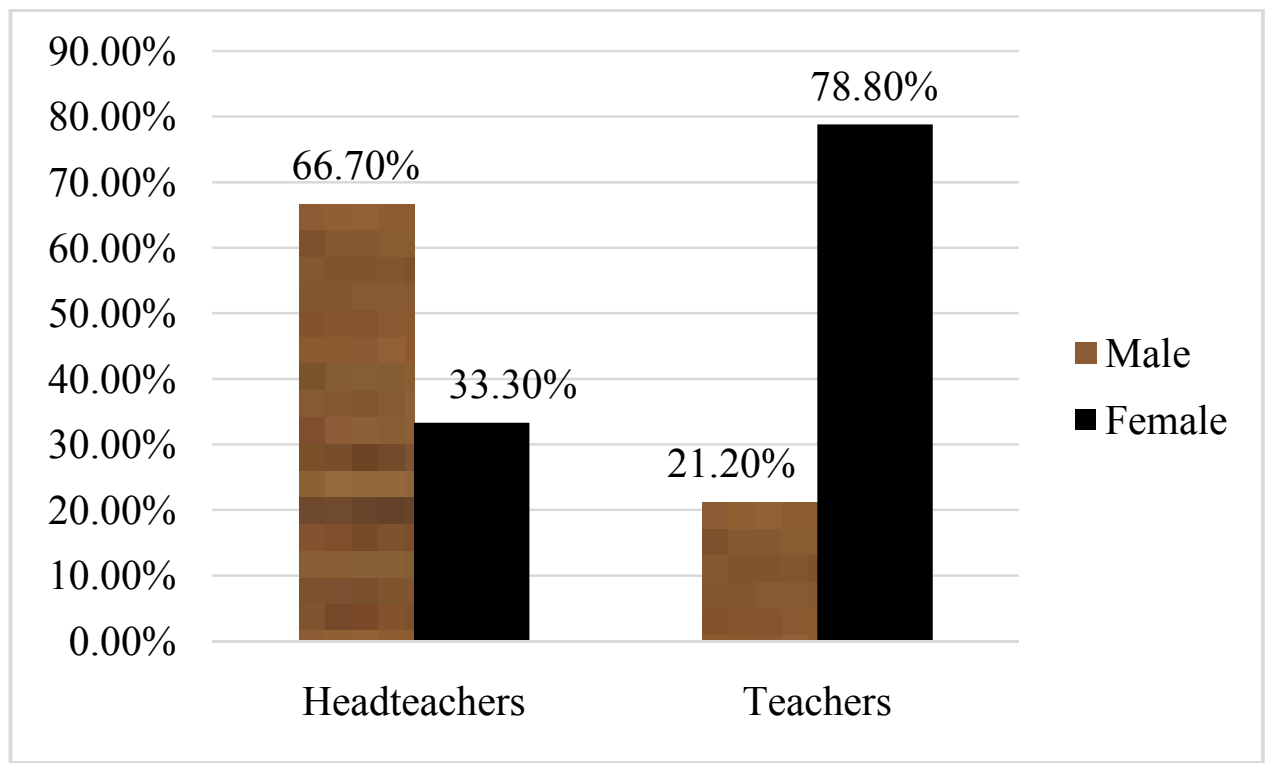

Figure 1: Gender /Sex of Respondents 
AGE OF RESPONDENTS

The results in Table 3 show that, $39.5 \%$ of the headteachers and $11.8 \%$ of the teachers were in age bracket of 49 years and above. It is also shown that $49.4 \%$ of the headteachers and teachers were aged 37 to 48 years, whereas
$11.1 \%$ of the headteachers and $34.1 \%$ of the teachers were aged 28 to 37 years, while $4.7 \%$ of the teachers were aged 18 to 27 years. This implied that in both cases the respondents participating in the study were in the age bracket of 37 years or above

Table 4: Age of Respondents

\begin{tabular}{llllll}
\hline & & \multicolumn{2}{l}{ Headteacher } & \multicolumn{2}{l}{ Teacher } \\
& & $\mathbf{F}$ & $\mathbf{\%}$ & $\mathbf{F}$ & $\mathbf{\%}$ \\
\hline Age of & $18-27$ years & 4 & $0.0 \%$ & 0 & $4.7 \%$ \\
Respondent & 28-37 years & 9 & $11.1 \%$ & 29 & $34.1 \%$ \\
& 37-48 years & 36 & $49.4 \%$ & 46 & $49.4 \%$ \\
& 49 years and above & 32 & $39.5 \%$ & 10 & $11.8 \%$ \\
& Total & $\mathbf{8 1}$ & $\mathbf{1 0 0 . 0 \%}$ & $\mathbf{8 5}$ & $\mathbf{1 0 0 . 0 \%}$ \\
\hline
\end{tabular}

\section{LENGTH OF SERVICE IN THE CURRENT STATION}

The results in Table 4 show that $71.6 \%$ of the headteachers and $84.7 \%$ of the teachers had been in their current workstation for a period above 3 years. The results also show that $22.2 \%$ of the headteachers and $10.6 \%$ of the teachers had been in their current workstation, while $6.2 \%$ of the headteachers and $4.7 \%$ of the teachers indicated a period below 1 year. The results suggest that majority of the teachers and headteachers had been in their current workstation for a period long enough to provide the information sought on the status of management of teaching and learning materials as well as on learners' performance in activity areas.

\section{Table 5: Length of Service in the Current Station}

\begin{tabular}{llllll}
\hline & & \multicolumn{2}{c}{ Headteachers } & \multicolumn{2}{l}{ Teachers } \\
& & $\mathrm{F}$ & $\%$ & $\mathrm{~F}$ & $\%$ \\
\hline How long have you & Below 1 year & 5 & $6.2 \%$ & 4 & $4.7 \%$ \\
been in the current & $1-3$ years & 18 & $22.2 \%$ & 9 & $10.6 \%$ \\
station? & Above 3 years & 58 & $71.6 \%$ & 72 & $84.7 \%$ \\
\hline
\end{tabular}

\section{Descriptive Statistics for Headteachers' Monitoring Allocations of Teaching And Learning Materials}

The results in Table 5 show that the responses from both the head teachers and teachers with respect to timeliness in allocating resources recorded similar outputs that is, 3.8750 and 3.8000 respectively. Both scores were above the 3.0 mean score neutral score. These results suggest that according to head teachers and teachers from most of the schools, timeliness in allocating resources had an influence on learners' performance in activity areas in Narok County. The results are similar to those in a study by Usman (2016), where it was established that timeliness in resource allocation was a predictor to the effectiveness of teaching and learning, and in extension learner performance.

The results in Table 5 with respect to equity in allocation of resources revealed that most the head teachers and teachers agreed that this had an influence on learners' performance in activity areas in their respective schools. The scores were as follows Headteachers' responses mean score of 3.9125 and teachers mean score of 3.9059. Both scores were above the 3.0 mean score neutral score. These results suggest that headteachers' role of ensuring equity in allocation of resources positively influenced learner performance in activity areas. The results are in agreement with Mwangi (2015) who established that equity in the distribution of resources made it possible for all the learners to access and utilize materials, and this favoured learner performance. 
The results in Table 5 reveal a similar pattern of response between the head teachers and teachers with respect to head teachers' monitoring of quality of teaching and learning materials and its influence on learners' performance. Their responses recorded the following mean score; head teachers (4.089) and teachers (3.9882). Both scores were above the 3.0 neutral mean scores. The head teachers' mean score was slightly above 4.0 , while the teachers score was slightly below 4.0. The results suggest that in the majority of the schools, learners' performance was enhanced through head teachers role of monitoring the quality of teaching and learning materials. The findings are in agreement with those in a study by Mascitti-Miller (2012), where it was established that the level and quality of the teaching and learning materials received by schools are crucial in determining the performance of learners.

The results in Table 5 with respect to the influence of human resource allocation by head teachers on learners' performance was as follows. The head teacher's response yielded a mean score of 4.0500 , while that of the teachers was 4.083 . Both scores were above 4.0 mean score, this implies that in majority of the schools, human resource allocation had an influence of learner's performance. The results were similar to those in a study by Ganira, Odundo and Muriithi (2016), who pointed that human resource allocation was key in determining learners' performance

The results in Table 5 show that the response with respect to sufficiency of teaching and learning materials allocated was as follows. The mean scores for the head teacher's response was 3. 800.while that of the teacher's response was 3.7738 . The value was greater than the 3.0 neutral mean score. This implied that sufficiency of teaching had an influence on learner's performance in activity areas. The results are similar to those in a study by Okongo, Ngao, Rop and Nyongesa (2015) where it was observed that insufficient teaching and learning resources had negatively affected learners' performance in preschool centers.

Table 6: Descriptive Statistics for Headteachers' Monitoring Allocations of Teaching and Learning materials

\begin{tabular}{|c|c|c|c|c|c|c|}
\hline & \multicolumn{3}{|c|}{ Head Teacher } & \multicolumn{2}{|c|}{ Teachers } & \multirow[b]{2}{*}{$\begin{array}{l}\text { Std. } \\
\text { Deviation }\end{array}$} \\
\hline & $\mathbf{N}$ & Mean & $\begin{array}{l}\text { Std. } \\
\text { Deviation }\end{array}$ & $\mathbf{N}$ & Mean & \\
\hline Timeliness in allocating resources & 80 & 3.8750 & 0.97273 & 85 & 3.8000 & 1.07792 \\
\hline Equity in allocation of resources & 80 & 3.9125 & 0.93041 & 85 & 3.9059 & 1.19147 \\
\hline Quality of teaching learning materials & 78 & 4.0897 & 0.91433 & 85 & 3.9882 & 1.07453 \\
\hline Human resource allocation & 80 & 4.0500 & 0.95334 & 84 & 4.0833 & 1.07780 \\
\hline $\begin{array}{l}\text { Sufficiency of teaching learning materials } \\
\text { allocated }\end{array}$ & 80 & 3.8000 & 1.11832 & 84 & 3.7738 & 1.20592 \\
\hline Valid N (listwise) & 78 & & & 84 & & \\
\hline
\end{tabular}

DESCRIPTIVE STATISTICS FOR LEARNERS PERFORMANCE IN ACTIVITY AREAS

The results in Table 4.11 show that learners' performance in activity areas recorded the following mean scores. Mathematics activities (headteachers $=2.7922$; teachers $=2.8916)$; Language activities (headteachers $=2.4615$; teachers $=2.6024$ ); Christian Religious Activities (headteachers $=2.9103$; teachers $=2.8916$ );
Environmental activities (headteachers $=2.9231$; teachers $=3.0723$ ); and Psychomotor \& Creative activities (headteachers $=2.9494$; teachers $=$ 2.9759). Overall, the means were below 3.0 neutral mean score. This implied that performance of learners' performance in activity areas was unimpressive. The lowest mean scores were in Language and Mathematics. 
Table 7: Descriptive Statistics for Learners Performance in Activity Areas

\begin{tabular}{lllllll}
\hline Activity Area & \multicolumn{3}{l}{ Headteachers } & \multicolumn{2}{c}{ Teachers } & \\
& N & Mean & Std. Deviation & N & Mean & Std. Deviation \\
& & & & & & \\
\hline Mathematics activities & 77 & 2.7922 & 0.56980 & 83 & 2.8916 & 0.60510 \\
Language activities & 78 & 2.4615 & 0.65846 & 83 & 2.6024 & 0.60364 \\
Christian Religious Activities & 78 & 2.9103 & 0.64839 & 83 & 2.8916 & 0.62493 \\
Environmental activities & 78 & 2.9231 & 0.57591 & 83 & 3.0723 & 0.57981 \\
Psychomotor \& Creative activities & 79 & 2.9494 & 0.65826 & 83 & 2.9759 & 0.76471 \\
Valid N (listwise) & 77 & & & 83 & & \\
\hline
\end{tabular}

Description of Learners' performance in Activity Areas by Quality Assurance Officers and ECD Coordinators'

The Quality Assurance Officers and ECD Coordinators in Narok County were asked to describe how they were able to assess learners' performance in activity areas in pre-schools in their area of administration. The responses were as follows: One of the QASO officers indicated: "I am able to monitor and evaluate performance through observation of learners and rating them using approved rating scales of: Exceeding Expectation, meeting expectation, approaching expectation and below expectation". This was the response provided by majority of the Quality Assurance Officers and ECD Coordinators in Narok County.

An ECD coordinator stated as follows: "As an administrative you go through teachers progress record made by the teacher of the learner and you are able to comprehend the learners' performance".
According to the most of the Quality Assurance Officers and ECD Coordinators' most of preschool learners in their administrative zones are at now approaching expectation in the following activity areas: Mathematics, Languages, Christian Religion, while environmental and psychomotor/creative activity most of them meet expectation.

A Centre performance tool was administered to the respondents and the results were as captured in Table 7. It was found that learners' performance levels reported the following mean scores, which were averages of number of leaners at each performance levels. The results were as follows: exceeding expectation (9.0714), meeting expectation (16.6706), approaching expectation (9.9529) and below expectation (5.3506). The results implied that most learners in the preschools were meeting expectation in activity areas. This was contrary to the results provided by the Quality Assurance Officers and ECD

Coordinators.

Table 8: Learners' Performance as captured by the Centre Performance Assessment Tool

\begin{tabular}{llllll}
\hline & N & Minimum & Maximum & Mean & Std. Deviation \\
\hline Exceeding expectation & 70 & 1.00 & 50.00 & 9.0714 & 9.44906 \\
Meeting expectation & 85 & 2.00 & 60.00 & 16.6706 & 10.13409 \\
Approaching expectation & 85 & 2.00 & 35.00 & 9.9529 & 6.55000 \\
Below expectation & 77 & .00 & 28.00 & 5.3506 & 4.30045 \\
Valid N (listwise) & 63 & & & & \\
\hline
\end{tabular}

Correlations between Monitoring of Teaching and Learning Materials and Learners' Performance in Activity Areas
The findings in Table 4.11 show that there was a negative Pearson correlation between headteachers' role of monitoring of teaching and learning materials and learners' performance in activity areas as follows: $\left(r=-0.021^{*}, p=0.785\right)$. 
This shows that there was no association between headteachers' role of monitoring of teaching and learning materials and learners' performance in activity areas. Given that, the $p$ value $(0.785)$, was less than the test significance level $(p<0.05)$, this relationship is statistically insignificant. The results are contrary to those in a survey by the Institute of Medicine and National Research Council (2015), where it was reported that monitoring of teaching and learning materials used ensured that the materials used were appropriate and were properly used for the enhancement of learners' performance.

Table 9: Correlations between Availing of Teaching and Learning Materials, and Learners' Performance

\begin{tabular}{llll}
\hline & & $\begin{array}{l}\text { Monitoring of Teaching and } \\
\text { Learning Materials }\end{array}$ & $\begin{array}{l}\text { Learners' Performance in } \\
\text { Activity Areas }\end{array}$ \\
\hline $\begin{array}{l}\text { Monitoring of Teaching and } \\
\text { Learning Materials }\end{array}$ & $\begin{array}{l}\text { Pearson } \\
\text { Correlation }\end{array}$ & 1 & -.021 \\
& Sig. (2-tailed) & 166 & .785 \\
\cline { 2 - 4 } & $\mathrm{N}$ & 166 \\
\hline $\begin{array}{l}\text { Learners' Performance in } \\
\text { Activity Areas }\end{array}$ & $\begin{array}{l}\text { Pearson } \\
\text { Correlation }\end{array}$ & -.021 & 1 \\
\cline { 2 - 4 } & Sig. (2-tailed) & .785 & 166 \\
\hline
\end{tabular}

\section{REGRESSION ANALYSIS}

Multiple regression analysis was done to establish the relationship between the independent and dependent variables and the results are presented in this section. The variables under investigation included Supervision in the use of teaching and learning materials, availing of teaching and learning materials, maintenance of teaching and materials, monitoring of teaching and learning materials, and adequacy of teaching and learning materials (independent variables) and learners' performance (dependent variable).

\section{MODEL SUMMARY}

The R Square value in the Model Summary table shows the amount of variance in the dependent variable that can be explained by the independent variables. The independent variables listed below Table 9 accounted for 6.1 percent of the variability in learners' performance in activity areas. The R-value (.247) is the multiple correlation coefficients between all the entered independent variables and the dependent variable. The Adjusted $\mathrm{R}$ Square adjusts for a bias as the number of variables increases. The Std. Error of the Estimate is a measure of the accuracy of the prediction.

Table 10: Model Summary

\begin{tabular}{lllll}
\hline Model & R & R Square & Adjusted R Square & Std. Error of the Estimate \\
\hline 1 & $.247 a$ & .061 & .055 & .41216 \\
\hline a. Predictors: (Constant), Monitoring of Teaching and Learning Materials
\end{tabular}

\section{ANALYSIS OF VARIANCES (ANOVA)}

In the study, the predictors are significant when Sig. ( $p$ value) $p<0.05$. The findings in Table 10 show that $p$ value was 0.001 . Since the $p$ values are less than 0.05 (confidence level), we can conclude that the influence of headteachers' managerial competencies is significant. As $p<$ 0.05 our predictors are significantly better than would be expected by chance. The regression line predicted by headteachers' managerial competencies explains a significant amount of the variance in the level of effectiveness of school management. This is reported as follows: $F(1,164)=10.683 ; p<0.05$, and therefore can conclude that the regression is statistically significant. 
Table 11: Analysis of Variances (ANOVA)

\begin{tabular}{lllllll}
\hline Model & Sum of Squares & df & Mean Square & F & Sig. \\
\hline $\begin{array}{l}\text { Regression } \\
\text { Residual }\end{array}$ & 1.815 & 1 & 1.815 & 10.683 & $.001 \mathrm{~b}$ \\
\hline \begin{tabular}{l} 
Rotal \\
\hline
\end{tabular} & 27.859 & 164 & .170 & & \\
\hline
\end{tabular}

a. Dependent Variable: Learners' Performance in Activity Areas

b. Predictors: (Constant), Monitoring of Teaching and Learning Materials

\section{BETA COEFFICIENTS}

Beta Coefficients presented in able 11 revealed the following. The regression model used was:

LPAA $=\beta_{0}+\beta_{1}$ MATLM $+\varepsilon$

LPAA $=2.409+0.115+0.139$

From the findings, it emerges that the beta value for headteachers role in monitoring of Teaching and Learning Materials (Beta $=0.115 ; p=0.001)$. The study hypothesis stated that ${ }^{\circ \mathrm{HO}_{2}}$ : There is no significant influence of monitoring of allocation of teaching and learning materials by headteachers on learners 'performance in activity areas, in public pre-primary schools in Narok County." Since the $p$ value associated with monitoring of Teaching and Learning Materials was 0.001 , which is less $0.05(p<0.05)$, the null hypothesis is rejected and therefore, the study holds that monitoring of allocation of teaching and learning materials by headteachers had a significant influence on learners' performance in activity areas, in public pre-primary schools in Narok

County.

Table 12: Beta Coefficients

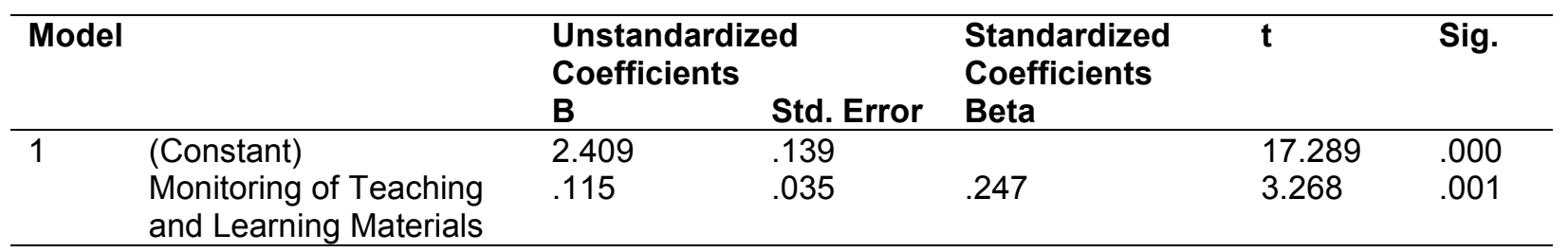

a. Dependent Variable: Learners' Performance in Activity Areas

\section{CONCLUSION}

The study concludes that some schools, the aspect of monitoring allocation of teaching and learning materials did not have influence on the performance in learners in activities areas. The study concludes that such inadequacies were seen in the case of timeliness in allocating resources. The failure to ensure equity in allocation of TLM by headteachers was affecting learners' performance in activity areas. Moreover, in some of the preschools, the head teachers had not been effective in monitoring the quality of teaching and learning materials, and their responses also demonstrate weakness in monitoring human resources allocation.

\section{RECOMMENDATIONS}

The study's recommendations were as follows.

i. The school management to scale up mobilization of resources for quality monitoring of the acquisition of teaching and learning in preschool. This will help ensure availability of maps, diagrams and fixed playthings.

ii. The school management should consider scaling up the processes and practices of monitoring the use of teaching and learning materials and ensure equity and timeliness in allocation of those materials. Properly coordinated monitoring of teaching and learning materials will ensure high quality of learners' performance. 
REFERENCES

Afework, T. H. and Asfaw, M. B., 2004 "The Availability of School Facilities and their Effects on the quality of education in Government

Primary Schools of Harari Regional State and East Hararghe Zone, Ethiopia" Middle Eastern and African Journal Research issues 11, 2004.

Cooper, D. and Schindler, P., 2013. Business Research Methods,12th Edition. The McGraw- Hill /Irwin

Dommeyer, C. J., Baum, P., Chapman, K. S. and Hanna, R. W., 2002. Attitudes of business faculty towards two methods of collecting teaching evaluations: Paper vs. online. Assessment and Evaluation in Higher Education (27)5, pp. 455-462.

Eddy, M., 2016. "'The Child Writer: Graphic Literacy and the Scottish Educational System, 1700-1820'". History of Education. 46: 695-718.

Farooq, M. U., 2013. Improving prediction accuracy of hard-to-predict branches using data value correlation.

Gall, G. and Gall, J. and Borg. P., 2003. Educational research: An introduction, 7.

Ganira K. Lilian, Paul A. Odundo, Muriithi Z. W., 2016. Influence of Head Teacher Management of Preschool Programs and Learning Achievement in Mombasa County, Kenya. Education Journal. Vol. 5, No. 5, 2016, pp. 81-91. doi: 10.11648/j.edu.20160505.11.

Gupta, K., 2001. A practical guide to needs assessment. Performance Improvement, 40(8), 40-42.

Hanushek, E. A., 2008. Educational Production Functions. The New Palgrave

Hanushek, E., 1995. Interpreting recent research on schooling in developing countries. The World Bank Research Observer, 10(2), 27-246.
Hirst, M., Jewis, W., Sojo, R and Cavanagh, S., 2011. Transition to Primary: A Review of the Literature. Retrieved From: Www.Kidsmatter.Edu.Au

Institute of Medicine and National Research Council 2015. Transforming the Workforce for Children Birth Through Age 8: A Unifying Foundation. Washington, DC: The National Academies Press. https://doi.org/10.17226/19401.

Karaka, K., 2007.Effective teaching in school. Oxford University Press, London.

KICD, 20I7.Facilitator's Training Manual for Early Years Education Curriculum. Nairobi: $\mathrm{KICD}$

Kothari, R. C., 2004. Research Methodology: Methods and Techniques, 2nded. Delhi: New Age International.

Labaree, R. V., 2009. Research Guides: Organizing Your Social Sciences Research Paper: Theoretical Framework.

Landrum, T. J., and McDuffie, K. A., 2010. Learning styles in the age of differentiated instruction. Exceptionality, 18(1), 6-17.

Likwop, P. K., 2016. Influence of Headteachers' Instructional Supervision Practices On Pupils' Performance in Kenya Certificate of Primary Education in Mulot Division, Narok South, Kenya. University of Nairobi.

Mascitti-Miller, E., 2012. "Resource Allocation: Practices in Urban Elementary Schools" (2012). Education Doctoral. Paper 19

Mbaka, T., 2012.Influence of Headteachers' Administrative Role on Kenya Certificate of Primary Examination Performance in Gucha South District, Kenya. University of Nairobi

Ministry of Education, Republic of Kenya 2017. Basic education curriculum framework. Nairobi: KICD.

Montessori, M., 1998.Discovery of child development. Oxford series London. 
Muithungu, C. E., 2003.Teaching resources for young children. Longhorn Publishers Nairobi

Mwangi, L., 2015. Effect of Dramatization on Learner Achievement in Learning English Language in Public Secondary Schools in Meru County, Kenya. University of Nairobi.

Mwonga, L. and Wanyama, W., 2012.Dealing with the prevailing attitudes and challenges for effective implementation of ECD Music and Movement Curriculum in Eldoret Municipality, Kenya. Research Journal in Organizational Psychology and Education Studies. 1(5), 295-302.

Narok County Education Office 2018.List of Public Pre-Primary Schools. MoE.

Ntumi, S., 2016.Challenges Pre-School Teachers Face in the Implementation of the Early Childhood Curriculum in the Cape Coast Metropolis. Journal of Education and Practice Vol.7, No.1, 54 66.

Offenheiser, R. and Holcombe, S., 2008. Challenges and opportunities in implementing a rights-based approach to development: An Oxfam America perspective. Nonprofit and Voluntary Sector Quarterly 32(2): 268.

Okendu, J. N., 2012. The impact of school administrative structure and adequate supervision on the improvement of instructional processes. Academic Research International Journal 2(3): pp.497-500.

Oluwafemi, O. L., Nma, A., Osita, O. and Olugbenga, O., 2014. Implementation of early childhood education: A case study in Nigeria. Universal Journal of Educational Research. 2(2): 119-125

Orodho, J. Waweru, P. Ndichu, M. and Nthinguri, R., 2013. Basic Education in Kenya: Focus on Strategies Applied to Cope with
School Based Challenges Inhibiting Effecting Effective Implementation of the Curriculum.

Orodho, J. A., 2008. Techniques of Writing Research Proposals and Reports in Education and Social Sciences. Bureau of Educational Research. Kenyatta University, Nairobi, Kenya: Kanezja HP Enterprises.

Republic of Kenya 2012. Sessional Paper No.14 of 2012 on realigning education and training to the Constitution of Kenya 2010 and Vision 2030 and beyond. Ministry of Education Science and Technology. Nairobi. Kenya.

Tuimur H. N. and Chemwei B., 2015.Availability and Use of Instructional Materials in the Teaching of Conflict and Conflict Resolution in Primary Schools in Nandi North District, Kenya. International Journal of Education and Practice. 3(6) 224-234.

UNESCO, 2010.Conference concept paper of The World Conference on Early Childhood Care and Education (ECCE): Building the Wealth of Nations. http://unesdoc.unesco.org/images/0018/0 01873/187376e.pdf (Accessed 3 June 2018.)

Usman, Y., 2016. Educational Resources: An Integral Component for Effective School Administration in Nigeria. Research on Humanities and Social Sciences Vol.6, No.13, 2016

Usman, Y. D., 2016. Educational Resources: An Integral Component for Effective School Administration in Nigeria. Online Submission, 6 (13), 27-37.

Wambua, A. W., 2015. Mobilization and Allocation of Teaching and Learning Resources among Subjects in Public Secondary Schools in Makueni County, Kenya.".Unpublished MoE Project, Kenyatta University, Nairobi. 